\title{
EVALUASI PROGRAM BSE (BUKU SEKOLAH ELEKTRONIK) DI SMP NEGERI KOTA YOGYAKARTA
}

\author{
Aris Suharyadi, Cepi Safruddin Abdul Jabar \\ Program Studi Manajemen Pendidikan PPs UNY, Universitas Negeri Yogyakarta \\ arisuharyadi@gmail.com, cepi_safruddin@uny.ac.id
}

\begin{abstract}
Abstrak
Penelitian ini bertujuan: (1) untuk menjelaskan pencapaian implementasi manajemen BSE (Buku Sekolah Elektronik) di SMP Negeri Kota Yogyakarta, dan (2) menjelaskan pencapaian tujuan program BSE (Buku Sekolah Elektronik) di SMP Negeri Kota Yogyakarta. Penelitian ini merupakan penelitian evaluasi dengan pendekatan kuantitatif. Hasil penelitian menunjukkan bahwa implementasi manajemen BSE (1) aspek perencanaan BSE termasuk dalam kategori "sangat efektif"; (2) aspek pengadaan BSE termasuk dalam kategori "sangat efektif"; (3) aspek inventarisasi BSE termasuk dalam kategori "efektif"; (4) aspek penyimpanan BSE termasuk dalam kategori "efektif"; (5) aspek penggunaan BSE termasuk dalam kategori "sangat efektif"; (6) aspek pemeliharaan BSE termasuk dalam kategori "sangat efektif"; (7) aspek penghapusan BSE termasuk dalam kategori "efektif". Pencapaian tujuan program BSE menunjukkan: (1) aspek menyediakan sumber belajar alternatif, ditinjau dari sisi guru termasuk dalam kategori "efektif" dan dari sisi siswa termasuk dalam kategori "cukup"; (2) aspek menstimulus siswa untuk berpikir kreatif dengan bantuan TIK (teknologi, infomasi, dan komunikasi), ditinjau dari sisi guru termasuk dalam kategori "efektif" dan dari siswa termasuk dalam kategori "efektif"; (3) aspek mematuhi regulasi pemerintah, ditinjau dari sisi guru termasuk dalam kategori "kurang" dan dari sisi siswa termasuk dalam kategori "kurang".

Kata kunci: evaluasi, manajemen, BSE (Buku Sekolah Elektronik).
\end{abstract}

\section{PROGRAM EVALUATION OF ESB (ELECTRONIK SCHOOL BOOK) IN PUBLIC JUNIOR HIGH SCHOOL YOGYAKARTA MUNICIPALITY}

Aris Suharyadi, Cepi Safruddin Abdul Jabar

Program Pascasarjana Manajemen Pendidikan PPs UNY, Universitas Negeri Yogyakarta arisuharyadi@gmail.com, cepi_safruddin@uny.ac.id

\begin{abstract}
This research aim to: 1) explain the attainment of management implementation of ESB (Electronic School Book) in public Junior High School Yogyakarta, and (2) describe goal attainment of ESB (Electronic School Book) in public Junior High School Yogyakarta. This evaluation research uses a quantitative approach. The results show that the implementation of the management of ESB is: (1) planning aspects of ESB included in the category "highly effective"; (2) procurement aspects of ESB included in the category "highly effective"; (3) inventory aspects of ESB included in the category "effective"; (4) storage aspects of ESB included in the category "effective"; (5) aspects of usage ESB included in the category "highly effective"; (6) maintenance aspects of ESB included in the category "highly effective"; (7) aspect of eliminating ESB included in the category "effective". The attainment of program goals of ESB shows: (1) the aspects providing alternative learning resources, in terms of the teacher included in the category "effective" and from the students included in the category of "sufficient"; (2) aspect stimulating students to think creatively with the assistance of ICT (information, communication, and technology), viewed from the side of the teacher included in the category "effective" and the students included in the category "effective"; (3) complying with government regulatory aspects, in terms of the teacher included in the category "poor" and from the students included in the category "poor".
\end{abstract}

Keywords: evaluation, management, ESB (Electronic School Book) 


\section{Pendahuluan}

Faktor geografis Indonesia yang luas dan terdiri atas banyak pulau menjadikan pendidikan belum bisa merata. Pemerataan tidak hanya terkait dengan ketersedian guru namun juga sarana dan prasarana pendukung termasuk di dalamnya adalah buku pelajaran. Sebagai salah satu sumber ilmu pengetahuan, buku menjadi instrumen penting dalam upaya meningkatkan mutu pendidikan dan mencerdaskan kehidupan bangsa.

Pemerataan distribusi buku pelajaran ke seluruh sekolah yang ada di Indonesia akan menghabiskan banyak biaya dan tenaga jika hanya mengandalkan cara konvensional yaitu mengirim buku-buku tersebut melalui jalur darat, laut, maupun udara. Memanfaatkan teknologi saat ini, yakni internet adalah salah satu cara mendistribusikan buku pelajaran yang sudah dikaji kelayakanya oleh Badan Standar Nasional Pendidikan (BSNP) melalui program yang diberi nama (Buku Sekolah Elektronik (BSE). Buku tersebut dibeli hak ciptanya oleh pemerintah dari beberapa penerbit maupun penulis yang sudah dipertimbangkan kesesuaianya dengan kurikulum. Buku tersebut kemudian dijadikan format dalam bentuk elektronik atau yang biasa dikenal dengan e-book yang kemudian bisa diunduh oleh semua pihak yang membutuhkanya.

Inovasi tersebut adalah sebuah penyesuaian teknologi dalam pendidikan, harapanya melalui BSE tersebut seluruh siswa dapat menikmati buku pelajaran yang murah ataupun gratis. Selain gratis, BSE ini juga bebas digandakan, disebarluaskan bahkan diperjual belikan dengan aturan dan prosedur yang sudah ditetapkan oleh Kemendikbud mengenai Harga Eceran Tertinggi (HET). BSE ini sebelum dicetak masih berupa e-book, maka untuk mendapatkan file-nya diperlukan komputer ataupun smartphone yang tersambung internet serta aplikasi lainya untuk membuka file hingga akhirya dapat dibaca. Langkah awal untuk mendapatkan BSE ini dengan mengakses salah satu dari beberapa situs yang disediakan, diantaranya www.bse- mahoni.com dan www.bse.depdiknas.go.id yang saat ini mulai mengembangkan aplikasi sehingga BSE dapat diakses dengan lebih mudah melalui tablet dan smartphone. Aplikasi "Buku BSE" tersebut dapat diunduh gratis melalui app store, google play dan windows store.

Melalui program BSE tersebut tentu diharapkan tidak ada lagi siswa yang kesulitan memperoleh buku pelajaran. Tujuan diselenggarakanya BSE ini berdasarkan Permendiknas No. 2 Tahun 2008 adalah menyediakan sumber belajar alternatif bagi siswa, merangsang siswa untuk berpikir kreatif dengan bantuan teknologi informasi, memberi peluang untuk menggandakan, mencetak, menyebarluaskan dan memperjualbelikan dengan ketentuan yang sudah diatur, dan yang terakhir tujuan BSE ini adalah guna memberikan peluang masyarakat untuk berwirausaha dengan menjualnya melalui prosedur yang telah ditentukan oleh kementerian (Litbang Kemendikbud, 2013).

Pada pelaksanaan program BSE ada beberapa kendala, menurut hasil penelitian yang dilakukan oleh Eveline (2011, p.1) yang berjudul "Pemanfaatan BSE (Buku Sekolah Elektronik) pada Guru Mata Pelajaran Produktif di Tiga SMK Negeri Wilayah Kota Yogyakarta" menyebutkan faktor penghambat pelaksanaan program BSE ini disebabkan kurangnya sosialisasi dari pemerintah kepada sekolah, maupun sekolah dalam hal ini kepala sekolah kepada guru dan siswa sehingga buku elektronik ini jarang digunakan pada proses pembelajaran.

Pada kenyataannya memang koordinasi antara pihak pusat dengan daerah masih belum terlihat terkait dengan pelaksanaan program BSE, ini diperkuat melalui hasil penelitian yang dilakukan oleh Zaenal, Maya, \& Mutia (2010, p.1) yang mengambil lokasi penelitian di SMA Negeri 8 Yogyakarta. Hasil penelitian menunjukkan salah satu faktor penghambat tujuan program BSE ini adalah tidak adanya pembagian wewenang antara Kemendikbud (Pusat) dengan Dinas Pendidikan Daerah sehingga sekolah dalam hal ini 
menjadi kurang termotivasi untuk menggunakan BSE.

Masalah selanjutnya terkait dengan BSE adalah petunjuk teknis (Juknis) yang belum tersedia dalam upaya prosedural implementasi program ini. Alasan tersebut diperkuat dengan hasil penelitian yang dilakukan oleh Siska, Sundarso, \& Slamet (2014, p.9) dengan tema "Evaluasi Program BSE (Buku Sekolah Elektronik) Kementrian Pendidikan Nasional Tingkat SMA di Kota Semarang". Penelitian tersebut menyebutkan bahwa salah satu faktor penghambat pencapaian tujuan BSE ini adalah belum adanya Petunjuk Teknis (Juknis) sebagai pemandu lembaga maupun sekolah untuk dapat melaksanakan program BSE sesuai prosedur.

Tujuan BSE yang terdapat pada website resmi puskurbuk (Pusat Kurikulum dan Perbukuan) terdiri atas empat poin utama. Pertama, menyediakan sumber belajar alternatif bagi siswa. Kedua, merangsang siswa untuk berpikir kreatif dengan bantuan TIK. Ketiga, memberi peluang kebebasan untuk menggandakan, mencetak, memfotocopy, mengalihmediakan, dan/atau memperdagangkan BSE tanpa prosedur perijinan, dan bebas biaya royalti sesuai dengan ketentuan yang diberlakukan Menteri. Keempat, memberi peluang bisnis bagi siapa saja untuk menggandakan dan mem-perdagangkan dengan proyeksi keuntung-an $15 \%$ sesuai dengan ketentuan yang diberlakukan Menteri

Tujuan tersebut belum seluruhnya tercapai, terutama dalam hal mencetak, menggandakan, mendistribusikan, menyebarluaskan BSE baik dari pihak sekolah maupun masyarakat, hanya beberapa pihak yang berkepentingan mengambil keuntungan yang terlibat secara langsung sedangkan orang tua maupun guru belum ada kesadaran untuk melakukan pencetakan, penggandaan, serta penyebarluasan BSE tersebut. Hasil penelitian Siska, Sundarso, \& Slamet (2014, p.9) di salah satu SMA di Semarang menyebutkan bahwa pendistribusian belum optimal dikarenakan BSE yang tersedia masih berbentuk digital atau softcopy sehingga jika diperlu- kan dalam bentuk fisik dan ingin digandakan belum tersedia.

Jumlah guru yang menguasai teknologi juga masih rendah, hal ini ditambah dengan kemauan serta komitmen guru untuk menggunakan buku elektronik ini juga masih sedikit. Salah satu hasil penelitian Fitriyah (2013, p.7) yang dilakukan di SMA Negeri 1 Tempel ikut membuktikan masalah ini, kemampuan guru di bidang IT yang masih kurang padahal sekolah telah menyediakan sarana prasarana yang baik untuk menunjang penggunaan BSE. Aturan Permendiknas disebutkan bahwa masa pakai buku minimal 5 tahun sehingga sewajarnya buku tersebut bisa dipergunakan secara langsung dengan mencetak tanpa harus melalui komputer, namun menurut Priyono (2012, p.2), masalahnya tidak semua perpustakaan sekolah melengkapi koleksi bukunya dengan BSE yang telah dicetak dan digandakan sehing-ga buku tersebut terasa kurang optimal dalam pemanfaatanya.

Berdasarkan beberapa masalah terkait dengan program BSE tersebut, maka penting rasanya melakukan evaluasi pada manajemen dan tujuan program tersebut. Rencana yang tertuang dalam tujuan program BSE tersebut juga belum sesuai dengan kenyataan yang terjadi di sekolah dan masyarakat. Beberapa kendala dan hambatan yang terjadi dalam pelaksanaan BSE juga dapat terlihat dalam penelitian ini. Hasil penelitian ini dapat memberikan informasi sebagai pertimbangan guna perbaikan dan pengembangan program BSE di sekolah. Evaluasi program BSE ini diadakan di 16 SMP Negeri yang ada di Kota Yogyakarta.

\section{Metode Penelitian}

Penelitian ini merupakan penelitian evaluasi yang menggunakan jenis evaluasi program dengan pendekatan kuantitatif. Model yang digunakan dalam penelitian ini adalah model "goal attainment" yang dikembangkan oleh Tyler dan merupakan model paling awal yang memfokuskan pada tingkat ketercapaiaan tujuan program. 
Tempat penelitian ini adalah SMP Negeri di wilayah Kota Yogyakarta. Sasaran penelitian ini adalah pengelola atau penanggungjawab BSE pada setiap sekolah, guru, dan siswa sebagai pengguna BSE. Waktu untuk penelitian ini dilakukan selama tiga bulan, pada bulan Maret 2015Mei 2015.

Subjek penelitian dalam penelitian ini adalah penanggungjawab BSE, guna memperoleh data mengenai manajemen BSE. Penanggungjawab BSE dapat berbeda-beda pada setiap sekolah (Kepsek, Wakasek, guru, TU) karena menurut Burhanudin (1998, p.7), yang bertanggung jawab tentang masalah sarana pendidikan yaitu para pengelola atau bagian tata usaha pendidikan. Subjek penelitian selanjutnya adalah guru dan siswa untuk menggali data mengenai pencapaian tujuan BSE.

Data penelitian ini berupa data kuantitatif. Teknik pengumpulan data menggunakan angket. Angket yang digunakan adalah angket dengan skala Guttman. Dalam penelitian ini data yang diperoleh dianalisis dengan teknik persentase. Adapun langkah-langkah dalam memberikan nilai dilakukan dengan cara memberikan penilaian terhadap setiap ketercapaian indikator pelaksanaan program dengan memberikan skor 1 (satu) untuk setiap skor yang dilaksanakan, skor 0 (nol) untuk indikator pelaksanaan program yang tidak dilaksanakan. Selanjutnya menghitung persentase ketercapaian dengan menjumlahkan kinerja yang dilaksanakan, kemudian dibagi dengan jumlah seluruh kriteria pelaksanaan program sesuai dengan standarnya, kemudian dikalikan 100.

Tabel 1. Konversi Data Kuantitatif ke Data Kualitatif dengan Kriteria Kuantitatif Tanpa Pertimbangan

\begin{tabular}{cc}
\hline Interval Skor & Data Kualitatif \\
\hline $81 \%-100 \%$ & Sangat Efektif \\
$61 \%-80 \%$ & Efektif \\
$41 \%-60 \%$ & Cukup \\
$21 \%-40 \%$ & Kurang \\
$<21 \%$ & Sangat Kurang \\
\hline
\end{tabular}

Guna mengetahui data hasil konversi kuantitatif ke kualitatif digunakan kriteria kuantitatif tanpa pertimbangan dari Arikunto \& Jabar (2014, p.35) seperti disajikan pada Tabel 1.

\section{Hasil Penelitian dan Pembahasan}

Implementasi Manajemen BSE di SMP Negeri Kota Yogyakarta.

Hasil penelitian mencakup aspek yang berkaitan dengan implementasi manajemen BSE di SMP Kota Yogyakarta. Aspek tersebut adalah perencanaan, pengadaan, inventarisasi, penyimpanan, penggunaan, pemeliharaan, dan penghapusan BSE.

Data hasil penelitian pada aspek perencanaan menunjukkan bahwa ketercapaiaan perencanaan BSE di SMP Negeri Kota Yogyakarta mencapai rata-rata $83,03 \%$. Skor yang dicapai ini menunjukkan bahwa secara umum proses perencanaan BSE di SMP Negeri Kota Yogyakarta tercapai dengan kriteria "Sangat Efektif".

Aspek perencanaan BSE didukung dengan dua capaiaan kegiatan yaitu needs assessment yang menunjukkan rata-rata 90,63\% dan keterlibatan stakeholders dalam proses perencanaannya dengan rata-rata $72,92 \%$.

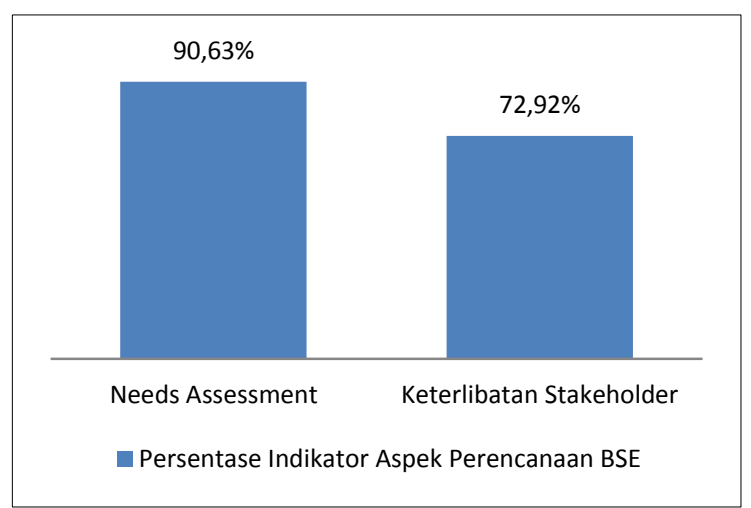

Gambar 1. Grafik Persentase Indikator Aspek Perencanaan BSE

Aspek perencanaan ini adalah bagian dari proses manajemen yang cukup penting untuk mengantisipasi masalah yang bisa ditimbulkan, dari pemborosan, kekurangan atau kerusakan fasilitas sekolah. 
Pernyataan yang senada disebutkan oleh Asiabaka (2008, p.14) bahwa perencanaan adalah salah satu tahapan manajemen fasilitas seperti berikut "management processes, which involve planning, organizing, decision making, leading, coordinating and controlling are applied in facilities management".

SMP Negeri di Kota Yogyakarta telah melakukan prinsip-prinsip perencanaan karena terlebih dahulu menganalisis kebutuhan BSE. Salah satu bagiannya adalah aspek needs assessment, memang belum sempurna karena belum mencapai 100\%. Berdasarkan data ternyata kekurangan paling banyak disumbangkan oleh masih kurangnya mempertimbangkan dana yang dimiliki oleh sekolah dalam aspek perencanaan ini. Mayoritas sekolah menggunakan dana BOS atau BOSDA untuk membeli BSE sehingga tidak perlu memikirkan ketersediaan dana.

Selanjutnya mengenai melibat-kan stakeholders dalam aspek perencanaan BSE. Sekolah sudah melibatkan guru bidang studi untuk memilih jenis buku mana yang akan dibeli oleh sekolah. Guru saja tentu tidak cukup untuk mendapatkan kesimpulan mengenai buku yang benar-benar sesuai dengan sekolah maupun siswa, oleh karena itu stakeholder perlu untuk berkontribusi, hal ini sejalan dengan pernyataan Asiabaka (2008, p.14) "Broadened educational goals and objectives as a result of changes in socio-economic development have necessitated the involvement of several minds in the facilities management process. It requires expert input from a wide range of stakeholders".

Semakin berkembangnya tujuan dan sasaran pendidikan tentu akan melibatkan semua pihak yang berkepentingan, oleh karena itu peran stakeholders pendidikan penting guna berkontribusi bagi perkembangan sekolah. Berdasarkan hasil penelitian, penyumbang kesenjangan terbanyak mengenai masih minimnya keterlibatan komite sekolah dan dinas pendidikan dalam merencanakan dan memberi masukan ketika merencanakan BSE. Hal ini disebabkan oleh berbagai faktor, salah satunya adalah komite sekolah yang selama ini hanya sebagai pelengkap dalam struktur organisasi sekolah. Perencanaan pengadaan buku masih dianggap belum terlalu penting untuk melibatkan komite dan dinas pendidikan karena menganggap yang lebih paham mengenai buku pelajaran adalah guru.

Hasil penelitian selanjutnya mengenai aspek pengadaan BSE yang menunjukkan bahwa ketercapaian proses pengadaan BSE di SMP Negeri Kota Yogyakarta mencapai rata-rata $83,82 \%$. Skor tersebut menggambarkan bahwa secara umum proses pengadaan BSE di SMP Negeri Kota Yogyakarta tercapai dengan kriteria "Sangat Efektif".

Aspek pengadaan BSE memiliki empat kegiatan pendukung, meliputi prosedur pengadaan yang menunjukkan ratarata $68,75 \%$, kualitas konten BSE 94,79\%, kuantitas BSE $89,58 \%$, dan tingkat rutinitas pengadaan BSE $81,25 \%$.

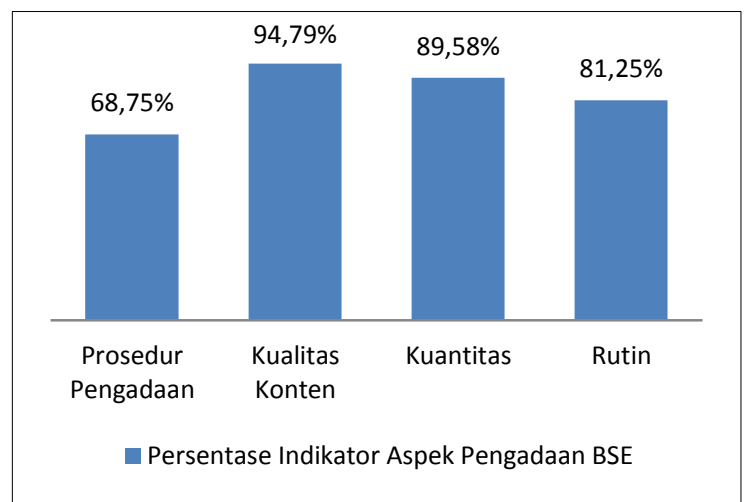

Gambar 2. Grafik Persentase Indikator Aspek Pengadaan BSE

Pengadaan BSE pada masing-masing sekolah sudah dilakukan dengan penyesuaian terlebih dahulu dengan kebutuhan sekolah. Pentingnya aspek pengadaan juga diungkapkan oleh Torlakson (2011, p.24) sebagai salah satu pengawas sekolah di California yang menyatakan bahwa dibutuhkan sistem yang efektif agar salah satunya dapat membantu proses pengadaan di sekolah "Proactively support needy districts in setting up effective systems in areas such as procurement, transportation, facilities, food service, maintenance, transportation, etc, rather than waiting until a district reaches a crisis point and needs substantial intervention".

Sekolah yang menggunakan kurikulum 2006 seluruhnya melibatkan pihak ke- 
3 atau percetakan sebagai penyedia BSE lalu kemudian meminjamkannya kepada siswa dan guru. Sekolah yang menggunakan kurikulum 2013 pengadaan BSE bisa berbeda beda pada setiap sekolah karena kebijakan internal sekolah yang menentukan.

Hal tersebut juga dilakukan untuk pengadaan fasilitas sekolah di California dengan memberikan instruksi kepada masing-masing sekolah untuk membuka ten0der terhadap barang dan jasa yang akan diadakan. "Establish a Superintendent's Council of Business/Labor to develop procurement criteria and to provide opportunities for procurement that promotes supplier diversity" (Torlakson, 2011, p.25). Prosedur pengadaan yang sudah ada pada setiap sekolah lebih cenderung kepada pengadaan BSE yang bersifat fisik atau yang sudah di cetak, sedangkan untuk versi $e$-book sekolah jarang yang memiliki. Hal ini cukup disayangkan sebenarnya karena dengan ikut menyediakan e-book dari BSE ini akan menambah koleksi buku pelajaran di sekolah.

Perkembangan teknologi saat ini sangat memungkinkan untuk bisa membaca sebuah $e$-book, karena jika dilihat mayoritas anak SMP sudah menggunakan smartphone. Penggunaanya saja yang perlu diarahkan oleh sekolah untuk lebih banyak berhubungan dengan pendidikan, misalnya untuk membaca atau mendownload e-book BSE. Hasil riset Nielsen On Device Meter (ODM) di Februari 2014 mencatat bahwa pengguna smartphone di Indonesia menghabiskan waktu rata-rata 140 menit per hari untuk menggunakan smartphone (Salim, 2014, p.1). Bukan tidak mungkin beberapa tahun kedepan semua siswa SMP telah memilki smartphone sehingga hanya tinggal upaya pihak terkait untuk lebih mengarahkan pada keperluan pendidikan.

Hasil penelitian selanjutnya adalah aspek inventarisasi BSE yang mencapai rata-rata $73,56 \%$. Skor yang dicapai ini menunjukkan bahwa secara umum proses inventarisasi BSE di SMP Negeri Kota Yogyakarta tercapai dengan kriteria "Efektif".

Aspek Inventarisasi BSE ini didukung dengan beberapa kegiatan didalam- nya. Kegiatan prosedur inventarisasi menunjukkan rata-rata $100 \%$, sekolah mengetahui jumlah BSE 100\%, sekolah mengetahui jenis atau kelompok BSE 100\%, sekolah mengetahui ukuran BSE 56,25\%, sekolah mengetahui kualitas fisik BSE $58,03 \%$, dan sekolah mengetahui tahun penerbitan BSE 93,75\%.

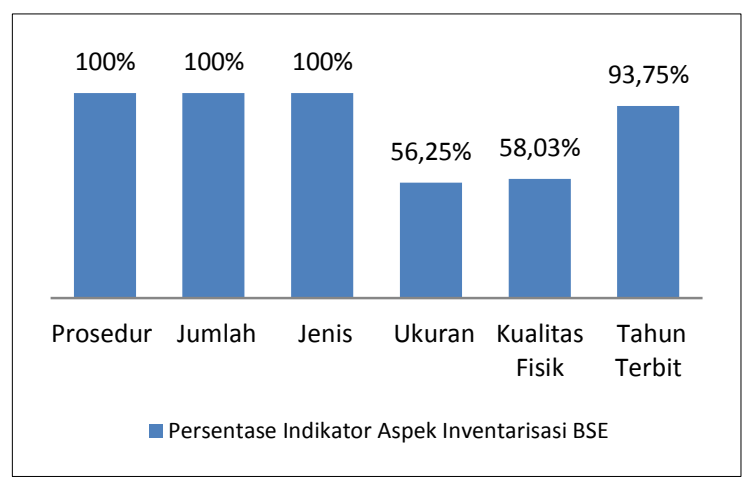

Gambar 3. Grafik Persentase Indikator Aspek Inventarisasi

Berkaitan dengan hal tersebut maka ada pendapat yang menyatakan bahwa mengembangkan alat inventarisasi itu penting untuk melihat kondisi kualitas fisik fasilitas sekolah karena dengan melihat data tersebut dapat diprediksi apakah fasilitas sekolah tersebut masih layak atau tidak, termasuk buku tersebut masih relevan atau tidak dengan kurikulum. Berikut kutipan tersebut, "Develop an inventory and assessment tool that measures the conditions and qualities of all California public school facilities" (Vincent, 2012, p.47).

Pengembangan alat inventaris tentu mengikuti spesifikasi dari fasilitas sekolah yang dimiliki. Sebuah buku berarti memiliki data terkait dengan nama pengarang, penerbit, jumlah halaman, ukuran dan tahun penerbitan. Secara keseluruhan aspek inventarisasi BSE sudah baik, yang kurang hanya pada data mengenai ukuran buku. Ukuran atau dimensi buku hanya didata oleh beberapa sekolah, padahal hal ini cukup penting untuk proses penyimpanan ataupun informasi bagi pengguna nantinya. Pentingnya informasi tersebut juga dijelaskan dalam pernyataan berikut ini "Preparing an inventory essentially involves gathering information on the availability and usage of services and facilities provided for the 
community" (Department of Sport and Recreation Government of Western Australia, 2007, p.9). Informasi terkait fasilitas umum yang ada di sekolah tentu wajib untuk didata karena itu juga dapat menjadi bukti pertanggungjawaban pengelola terhadap uang negara yang dibelanjakannya. Buku misalnya akan diketahui mana saja yang sudah berusia lebih dari lima tahun dan tidak relevan lagi maka dapat disingkirkan. Pendataan tersebut dilakukan secara terus menerus agar kondisi barang dengan data tetap sesuai. Hal ini juga disampaikan oleh Vincent (2012, p.47) "The database would serve as a statewide inventory of schools and should include a building conditions assessment that is periodically updated".

Hasil penelitian selanjutnya adalah aspek penyimpanan BSE yang mencapai rata-rata $65,95 \%$. Skor yang dicapai ini menunjukkan bahwa secara umum proses penyimpanan BSE di SMP Negeri Kota Yogyakarta tercapai dengan kriteria "Efektif".

Aspek penyimpanan BSE ini memiliki beberapa kegiatan pendukung di dalamnya. Kegiatan prosedur penyimpanan BSE mencapai rata-rata $62,50 \%$, sekolah menyimpan BSE versi cetak $81,25 \%$, sekolah menyimpan BSE versi elektronik $46,87 \%$, kemudahan dalam akses pencarian BSE $62,50 \%$, ketersediaan alat dan sarana guna menunjang aspek penyimpanan BSE $67,50 \%$, kedisiplinan dalam hal jangka waktu penyimpanan BSE $82,50 \%$, dan keadaan fisik BSE ketika disimpan 35,42\%.

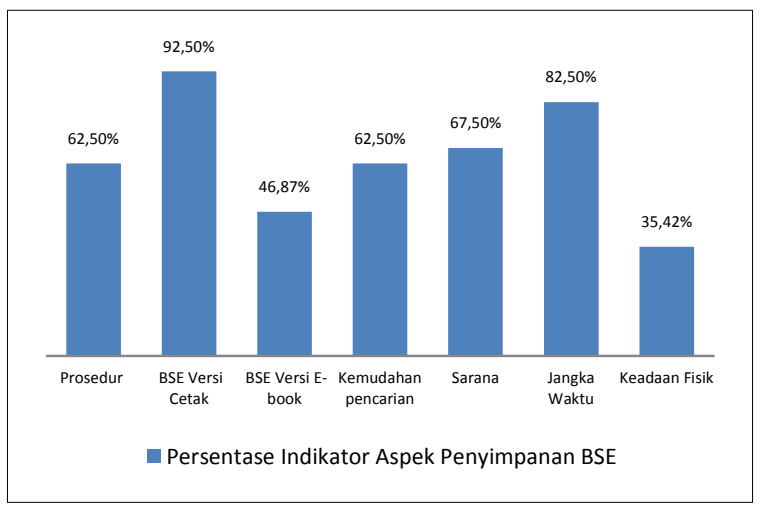

Gambar 4. Grafik Persentase Indikator Aspek Penyimpanan BSE

Penyimpanan BSE mayoritas dilakukan di perpustakaan. Hanya empat sekolah yang melakukan penyimpanan BSE untuk yang versi $e$-book, padahal ini juga penting apabila dalam kegiatan belajar membutuhkan referensi lain yang sekiranya lebih relevan. Versi $e$-book juga dapat menghemat kertas dan media penyimpanan. Perkembang zaman pasti pada akhirnya akan menuju ke arah paperless, namun memang masih perlu penyesuaian untuk orang indonesia. Hal ini juga turut disampaikan oleh Zickuhr (2012, p.8) yang menyatakan bahwa "Leading-edge librarians and patrons say that the advent of e-books has produced a major transformation in book searching and borrowing at libraries".

Berdasarkan hal tersebut seharusnya sekolah memperbanyak pengadaan dan penyimpanan BSE yang bebentuk softcopy. Hal lain yang perlu dibahas adalah mengenai masih kurangnya kesadaran pengguna BSE untuk menjaga kondisi buku agar tetap baik. Setiap tahun para siswa wajib mengembalikan BSE yang telah mereka pinjam. Buku tersebut akan digunakan kembali untuk adik kelasnya, siklusnya seperti itu hingga buku tersebut sudah tidak bisa digunakan.

Hasil penelitian selanjutnya adalah aspek penggunaan BSE yang mencapai rata-rata $83,59 \%$. Skor yang dicapai ini menunjukkan bahwa secara umum proses penggunaan BSE di SMP Negeri Kota Yogyakarta tercapai dengan kriteria "Sangat Efektif".

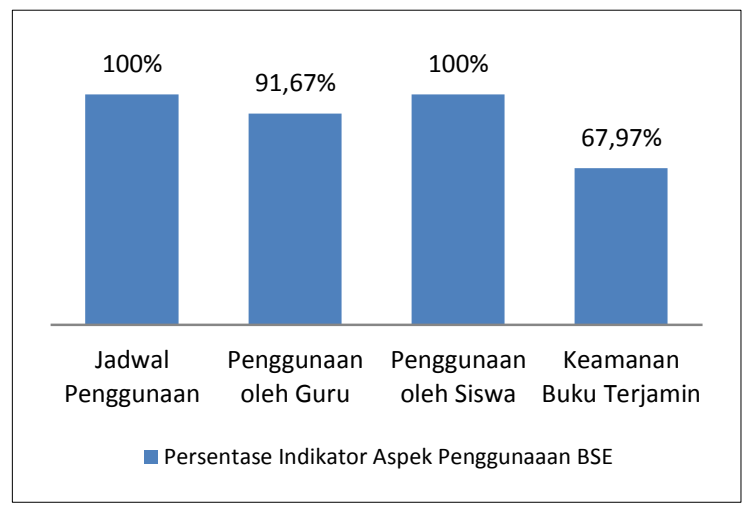

Gambar 5. Grafik Persentase Indikator Aspek Penggunaaan BSE

Aspek penggunaan BSE ini memiliki beberapa kegiatan pendukung di dalamnya. Kegiatan penyediaan jadwal penggu- 
naan BSE menunjukkan rata-rata $100 \%$, penggunaan BSE oleh guru 91,67\%, penggunaan BSE oleh siswa $100 \%$, keamanan BSE terjamin ketika dipinjam $67,97 \%$.

BSE yang diadakan sekolah di pinjamkan kepada siswa dan guru untuk menunjang kegiatan belajar. Penggunaan ini tidak serta merta menjadi milik siswa ataupun guru, namun pada akhir tahun nanti wajib dikembalikan. Dalam penggunaan ini juga sama bahwa kondisinya para pengguna yang dipinjamkan oleh sekolah masih banyak yang tidak bertanggung jawab untuk menjaga buku tersebut dari kerusakan maupun kehilangan.

Pengawasan tidak mungkin bisa dilakukan untuk menjaga agar setiap buku yang sedang digunakan oleh siswa maupun guru dalam keadaan baik. Pada intinya adalah menerapkan kedisiplinan terhadap seluruh pengguna baik itu siswa maupun guru adalah kunci agar buku tetap dalam keadaan baik.

Hasil penelitian selanjutnya adalah aspek pemeliharaan BSE yang mencapai rata-rata $91,25 \%$. Skor yang dicapai ini menunjukkan bahwa secara umum proses pemeliharaan BSE di SMP Negeri Kota Yogyakarta tercapai dengan kriteria "Sangat Efektif".

Aspek pemeliharaan ini didukung dengan capaian kegiatan prosedur pemeliharaan BSE yang menunjukkan rata-rata $90,63 \%$, rutin dalam pemeliharaan BSE $93,75 \%$, dan tersedianya biaya pemeliharaan BSE $87,5 \%$.

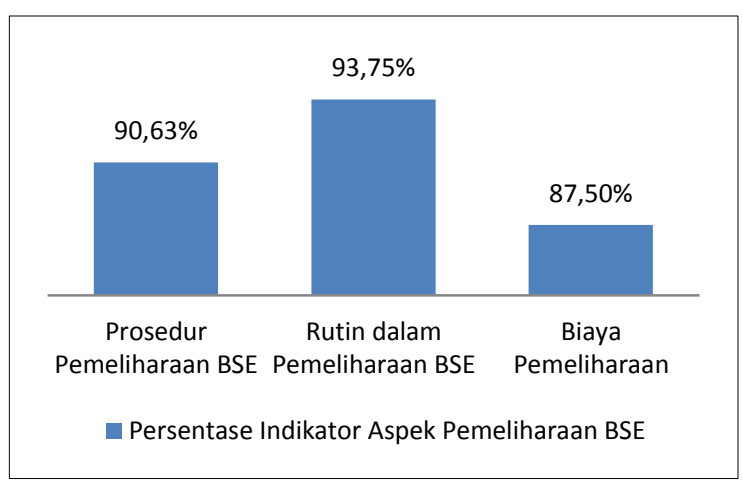

Gambar 6. Grafik Persentase Indikator Aspek Pemeliharaan BSE

Proses pemeliharaan dilakukan untuk barang yang biasa digunakan untuk jangka waktu lama seperti BSE. Pemeliharaan buku ini dilakukan ketika sedang disimpan di perpustakaan. Menurut Frantsi, Kolu, \& Salminen (2002, p.9) kegiatan pemeliharaan bisa dilakukan dengan "organises the catalogueing, covering the books with plastic, organises the borrowing, and other book maintenance work". Hal ini belum dilakukan oleh beberapa sekolah tempat penelitian berlangsung. Sampul yang biasa diberikan pada saat buku baru ternyata ketika digunakan dan dikembalikan ke sekolah sudah tidak bersampul dan banyak yang rusak ataupun hilang.

Mengacu pada pernyataan Frantsi, Kolu, \& Salminen (2002, p.12) "The planning of acoustics, lighting and electricity, air conditioning and maintenance should be done properly" tentu sedikit berbeda dengan hasil penelitian yang didapat karena pemeliharaan tidak sampai tuntas dikarenakan sulitnya menjaga buku yang dipinjam untuk umum agar tetap dalam keadaan baik. Pentingnya aspek pemeliharaan ini ternyata tidak seluruh sekolah mengalokasikan dana untuk kegiatan pemeliharaan BSE.

Hasil penelitian selanjutnya adalah aspek peghapusan BSE yang mencapai rata-rata $76,56 \%$. Skor yang dicapai ini menunjukkan bahwa secara umum proses penghapusan BSE di SMP Negeri Kota Yogyakarta tercapai dengan kriteria "Efektif".

Aspek penghapusan BSE ini didukung dengan capaiaan kegiatan prosedur penghapusan BSE yang menunjukkan ratarata $81,25 \%$ dan waktu penghapusan BSE $75 \%$.

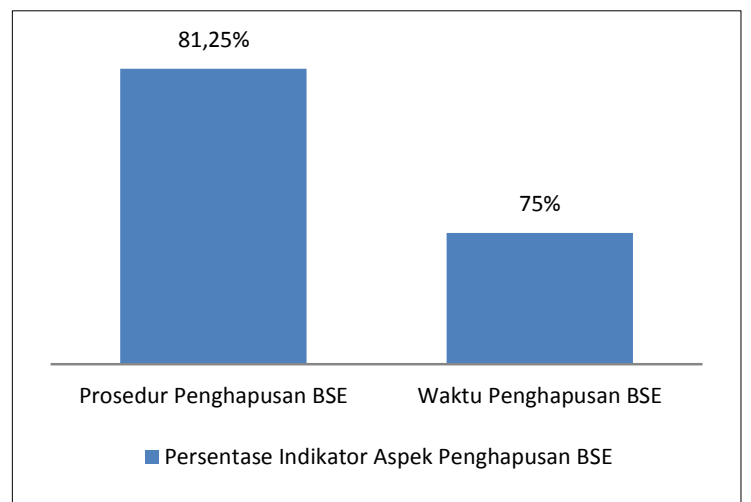

Gambar 7. Grafik Persentase Indikator Aspek Penghapusan BSE 
Penghapusan BSE dilakukan apabila buku tersebut sudah tidak bisa digunakan lagi akibat beberapa hal, misalnya tidak relevan akibat pergantian kurikulum atau memang buku tersebut sudah rusak parah sehingga lebih baik membeli buku baru daripada memperbaiki. Kegiatan penghapusan juga dinyatakan penting sebagai salah satu langkah dalam pengelolaan koleksi perpustakan, "Collection work and the management of the collection: selection of material, acquisition of material, elimination of material, evaluation of material" (Frantsi, Kolu, \& Salminen, 2002, p.13). Dalam hal ini sebagian besar sudah melakukan identifikasi setiap tahunnya untuk memisahkan antara buku yang masih bisa digunakan atau yang tidak.

BSE merupakan buku pelajaran sekolah yang berbentuk elektronik, namun memungkinkan untuk dicetak dan digunakan layaknya buku pelajaran sekolah konvensional. BSE saat ini tersedia untuk jenjang pendidikan SD, SMP, SMA maupun SMK. Mengelola BSE adalah bagian dari manajemen fasilitas di sekolah. Mewujudkan sekolah yang berkualitas tentu melibatkan seluruh elemen sekolah, hal ini sejalan dengan pendapat Nik-Mat, Kamaruzzaman, \& Pitt (2011, p.329) yang menyatakan bahwa "Facilities Management (FM) is a resource management that combines people, property and process management expertise to provide vital services in support of the organization". Memberdayakan sumber daya yang ada di sekolah untuk mengelola fasilitasnya guna mewujudkan organisasi yang profesional adalah penting.

Keberlangsungan organisasi pendidikan sangat dipengaruhi bagaimana elemen yang ada di dalamnya untuk bisa bersinergi mengelola fasilitas sekolah termasuk buku, hal tersebut sesuai dengan pernyataan Certo \& Certo (2012, pp.7-8) yakni "management is the process of reaching organizational goals by working with and through people and other organizational resources". Sekecil apapun sumber daya organisasi tentu memiliki fungsi tersendiri yang mengakibatkan secara keseluruhan proses dapat berjalan dengan lancar. Termasuk di dalamnya adalah fasilitas atau sarana prasarana pendidikan.

Implementasi manajemen BSE di SMP Negeri Kota Yogyakarta secara umum sudah bisa terlaksana. Masing-masing sekolah sudah memiliki penanggungjawab BSE yang mayoritas adalah dari kalangan pustakawan sekolah, namun ada pula sekolah yang menyerahkan tanggung jawab perihal BSE pada kepala sekolah, Wakasek bidang kurikulum dan guru. Melalui para pengelola di sekolah tersebut implementasi manajemen BSE diterapkan dengan proses manajemen dari perencanaan hingga pada tahap penghapusan BSE.

Adapun rekapitulasi proses manajemen BSE di SMP Kota Yogyakarta secara keseluruhan dapat dilihat melalui grafik pada Gambar 8.

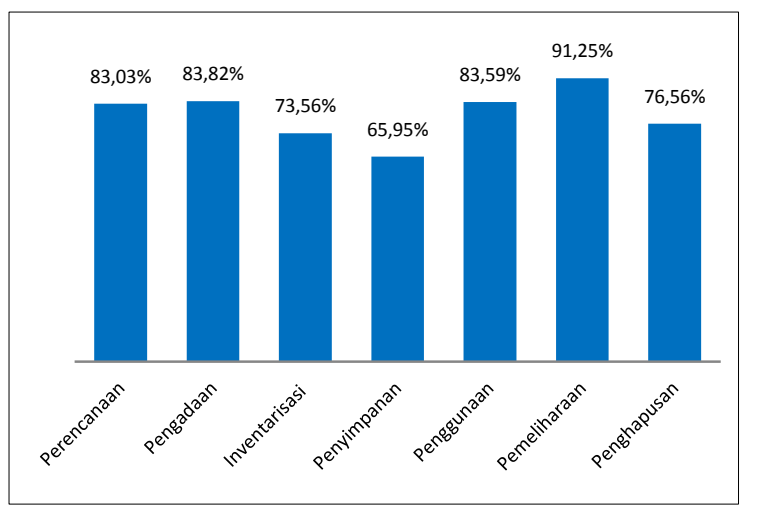

Gambar 8. Grafik Rekapitulasi Capaian Manajemen BSE

Tujuan Program BSE

Hasil penelitian mencakup aspek yang berkaitan dengan tujuan program BSE. Aspek tersebut adalah menyediakan sumber belajar alternatif bagi siswa, menstimulus siswa untuk berpikir kreatif dengan bantuan TIK, dan mematuhi regulasi pemerintah terkait dengan pelaksanaan program BSE.

Data hasil penelitian pada aspek BSE sebagai sumber belajar alterntif menunjukkan bahwa ketercapaian BSE sebagai penyedia sumber belajar alternatif di SMP Negeri Kota Yogyakarta ditinjau dari sisi guru mencapai rata-rata $68,31 \%$ dengan kriteria "Efektif" dan dari sisi siswa 50,94\% dengan kriteria "Cukup". 
Aspek menyediakan sumber belajar alternatif memiliki beberapa indikator dalam pencapaiaannya, adapun perbandingan antara tingkat ketercapaiaan guru dan siswa dapat dilihat seperti pada Gambar 9.

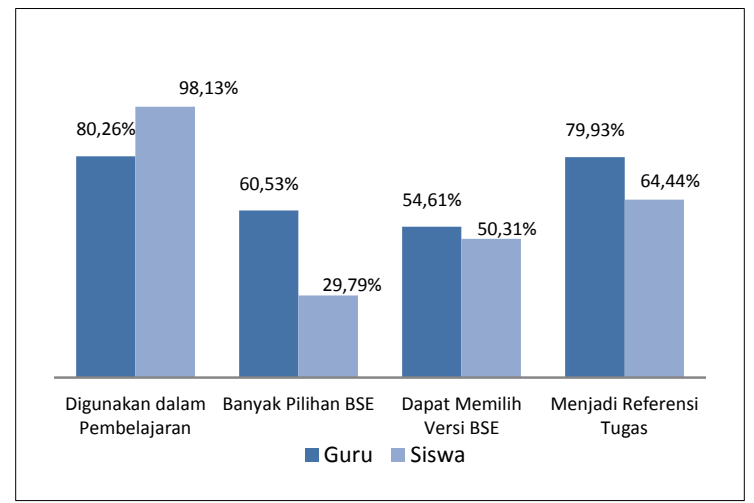

Gambar 9. Grafik Indikator Tujuan BSE dalam Menyediakan Sumber Belajar Alternatif

BSE telah digunakan oleh seluruh SMP Negeri di Kota Yogyakarta, namun untuk beberapa mata pelajaran muatan lokal belum disediakan oleh pemerintah. BSE yang diperuntukan bagi guru sebagai buku ajar ternyata tidak sebaik penggunaan oleh siswa. Hal tersebut memang otoritas penuh seorang guru di masingmasing sekolah ingin menggunakan terbitan dari pemerintah ataupun yang penerbit lainnya yang dianggap lebih sesuai.

Mayoritas sekolah hanya menyediakan BSE untuk versi cetaknya saja. Hal tersebut membuat siswa dan guru juga lebih banyak menggunakan BSE yang versi cetaknya daripada menggunakan e-book. Penelitian yang melibatkan anggota perpustakaan di Amerika pada tahun 2012 mengindikasikan bahwa mereka lebih suka membaca e-book, hal tersebut dijelaskan sekitar $46 \%$ responden mengaku sangat ingin meminjam gadget untuk membaca e-book di perpustakaan. Kutipannya sebagai berikut " $46 \%$ of those who do not currently borrow ebooks from libraries say they would be "very" or "somewhat" likely to borrow an e-reading device that came loaded with a book they wanted to read." (Zickuhr, 2012, p.6). Dengan demikian dapat diprediksi masa yang akan datang banyak perpustakaan yang menyediakan gadget atau perangkat pembaca $e$ - book yang di dalamnya tersedia buku yang diinginkan oleh anggota.

Data hasil penelitian selanjutnya adalah BSE dapat menstimulus siswa untuk berpikir kreatif dengan bantuan TIK, ditinjau dari sisi guru 77,56\% dengan kriteria "Efektif" dan dari siswa 64,01\% dengan kriteria "Efektif".

Aspek menstimulus siswa untuk berpikir kreatif ini memiliki beberapa indikator dalam pencapaiaannya, adapun perbandingan antara tingkat ketercapaiaan guru dan siswa dapat dilihat seperti pada Gamabar 10.

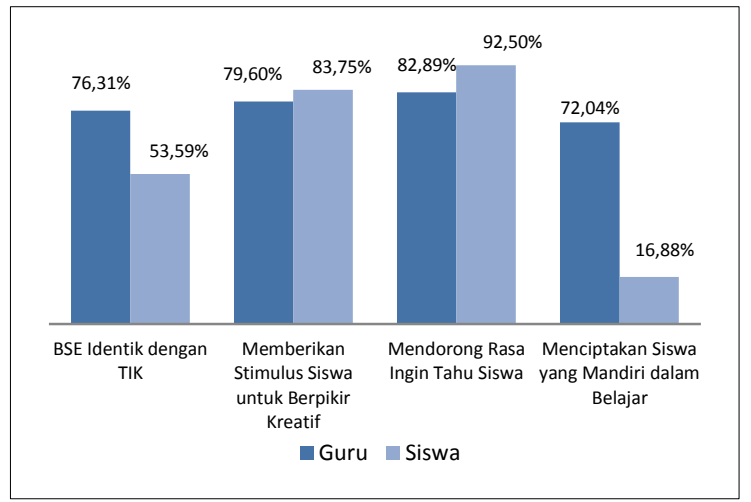

Gambar 10. Grafik Indikator Tujuan BSE dalam Menstimulus Siswa Berpikir Kreatif Melalui TIK

Tidak semua siswa menganggap bahwa BSE ini identik dengan TIK, hal ini wajar karena siswa SMP hanya mengerti BSE ini adalah buku pelajaran yang dipinjamkan oleh sekolah. Inisiatif siswa untuk mencari tahu lebih banyak jenis BSE melalui TIK masih sangat minim.

Hal selanjutnya mengenai masih rendahnya persentase siswa untuk bisa mandiri dalam belajar dengan menggunakan BSE. Melalui BSE ternyata belum mampu membangkitkan semangat belajar mandiri bagi para siswa. Hampir serupa dengan $e-$ learning, siswa dituntut untuk bisa mengembangkan kemampuan berpikir dari berbagai referensi dengan mandiri. Pada kenyataannya ternyata harus ada stimulus dari guru untuk memberikan instruksi kepada siswa agar bersedia belajar menggunakan BSE. Ketersediaan sumber belajar yang gratis seharusnya dimanfaatkan dengan optimal oleh semua pihak, khususnya 
bagi guru dan siswa untuk membangkitkan semangat belajar mandiri. Hasil penelitian Embong, Noor, Hasyim, et al (2012, p.1807) mengungkapkan hal senada "The emergence of e-Books as textbooks among the school children requires all parties (i.e. teachers, technologist, parents and even policy makers) to think how to adapt themselves in using $e$ Book". Penggunaan E-book sebagai salah satu buku pelajaran di sekolah diperlukan penyesuaian dari berbagai hal oleh semua pihak agar penggunaanya dapat optimal.

Pengembangan dalam sisi aplikasi sudah coba dilakukan oleh pemerintah Indonesia dengan membuat "aplikasi BSE" untuk beberapa sistem operasi di smartphone, mulai dari android, windows, hingga ios (apple). Aplikasi tersebut masih terhitung baru sehingga belum bisa dikatakan efektif atau tidak, di Tokyo tenyata aplikasi pembaca e-book yang dinilai paling baik oleh penggunannya terdapat pada sistem operasi ios (apple) "The verification result shows that iBooks3 on iOS worked best among the 6 e-book readers. Also it shows that many ebook readers support only representation of ePub2 files, while HTML5, JavaScript, and Web API are not supported yet" (Nakajima, Shinohara, \& Tamura, 2013, p.1344).

Data hasil penelitian selanjutnya adalah mematuhi regulasi pemerintah, dari sisi guru 33,93\% dengan kriteria "Kurang" dan dari sisi siswa 25,16\% dengan kriteria "Kurang".

Aspek mematuhi regulasi pemerintah in memiliki beberapa indikator dalam pencapaiaannya, adapun perbandingan antara tingkat ketercapaiaan guru dan siswa dapat dilihat pada Gambar 11.

Tujuan program BSE yang terakhir ini lebih kepada memberikan peluang kepada masyarakat untuk bisa berwirausaha. BSE secara bebas diunduh, digandakan, diperjual belikan oleh siapa saja dengan ketentuan HET dari pemerintah. Pada kenyataanya memang percetakan masih lebih dipercayakan sekolah untuk mengadakan BSE. Pertimbangan dalam hal kualitas buku yang dihasilkan dan pertanggung jawaban yang jelas karena percetakan telah resmi terdaftar sebagai badan usaha yang menjadikan pengadaan dipercayakan kepada pihak percetakan.

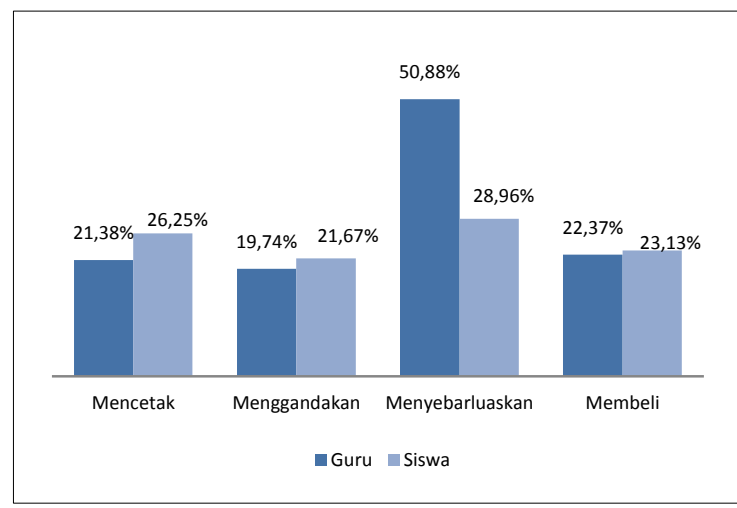

Gambar 11. Grafik Indikator Tujuan BSE dalam Mematuhi Regulasi Pemerintah

Peran masyarakat sebagai stakeholders pendidikan sebenarnya dapat dilihat dari tercapainya tujuan BSE mengenai mematuhi regulasi pemerintah ini. Dilihat dari sisi pengguna langsung yaitu siswa dan guru, ternyata hasilnya masih sangat rendah. Paling tinggi hanya mengenai guru yang menyebarluaskan BSE, selebihnya masih sangat kurang. Siswa tidak begitu aktif dalam mencari referensi secara mandiri, harus ada stimulus dari guru sehingga kegiatan untuk mencetak sendiri serta menyebarluaskan BSE tidak banyak dilakukan.

Pada sisi guru juga terlihat rendah dalam hal mentaati regulasi pemerintah, padahal undang-undang telah memberikan kelonggaran yang memperbolehkan menggandakan dan menyebarluaskan BSE. Inovasi yang terus berkembang untuk mewujudkan pendidikan yang berkualitas tentu memerlukan penyesuaiaan dari seluruh pihak. Salah satunya adalah penggunaan BSE yang memerlukan waktu untuk semua elemen pendidikan dapat menggunakannya secara efektif dan efisien. Negara tetangga yaitu Malaysia ternyata memiliki sistem pengembangan dan penerbit yang sepenuhnya diatur oleh pemerintah, sama halnya dengan Indonesia. "The development and publishing process of text books into e-Book may be different from one country to another. In Malaysia, this process is subject to the control of the Ministry of Education which has 
full copyright of the publication". (Embong, Noor, Hasyim, et al, 2012, p.1807).

Tujuan merupakan hasil akhir yang diharapkan oleh pembuat kebijakan, dalam hal ini adalah program BSE. Melalui kegiatan manajemen BSE yang sebelumnya telah dibahas tentu maksudnya adalah agar tujuan program BSE ini terlaksana. Seperti yang dikemukakan oleh Prasojo \& Wibowo (2014, p.60) bahwa “...manajemen sebagai suatu proses teknis untuk mencapai tujuan, selanjutnya lebih menekankan pada orang yang terlibat dalam proses manajemen". Tujuan program BSE ini memiliki setidaknya tiga aspek yang termuat dalam situs (Pusat Kurikulum dan Perbukuan (Puskurbuk).

Adapun rekapitulasi hasil capaian tujuan program BSE secara keseluruhan di SMP Negeri Kota Yogyakarta disajikan pada Gambar 12.

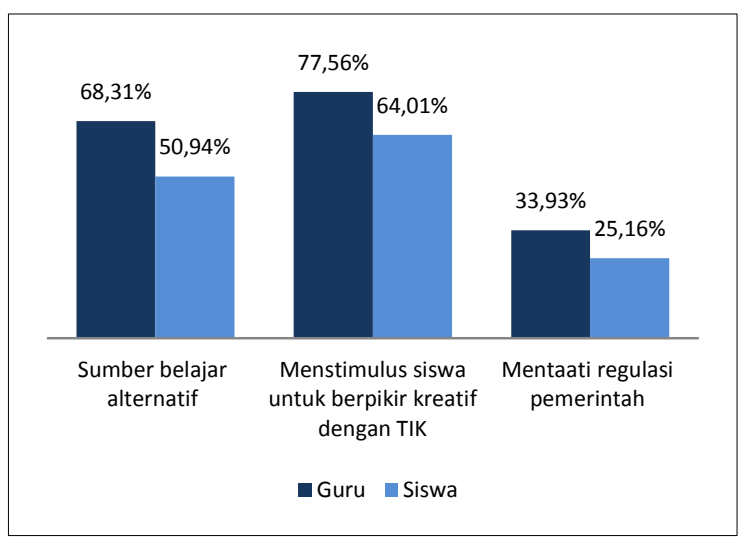

Gambar 12. Grafik Rekapitulasi Hasil

Capaiaan Tujuan Program BSE di SMP Negeri Kota Yogyakarta

\section{Simpulan dan Saran}

Simpulan

Tingkat ketercapaiaan implementasi manajemen BSE di SMP Negeri Kota Yogyakarta adalah sebagai berikut. Aspek perencanaan BSE termasuk dalam kategori "Sangat Efektif", hal tersebut didukung dengan capaiaan kegiatan needs assessment $90,63 \%$ dan keterlibatan stakeholders $72,92 \%$. Aspek pengadaan BSE termasuk dalam kategori "Sangat Efektif", hal tersebut didukung dengan capaian kegiatan prosedur pengadaan 68,75\%, kualitas konten BSE
94,79\%, kuantitas BSE 89,58\%, dan tingkat rutinitas pengadaan BSE $81,25 \%$.

Aspek inventarisasi BSE termasuk dalam kategori "Efektif", hal tersebut didukung dengan capaiaan kegiatan prosedur inventarisasi $100 \%$, sekolah mengetahui jumlah BSE $100 \%$, sekolah mengetahui jenis atau kelompok BSE 100\%, sekolah mengetahui ukuran BSE 56,25\%, sekolah mengetahui kualitas fisik BSE 58,03\%, dan sekolah mengetahui tahun penerbitan BSE $93,75 \%$.

Aspek penyimpanan BSE termasuk dalam kategori "Efektif", hal tersebut didukung dengan capaian kegiatan prosedur penyimpanan BSE $62,50 \%$, sekolah menyimpan BSE versi cetak $81,25 \%$, sekolah menyimpan BSE versi elektronik 46,87\%, kemudahan dalam akses pencarian BSE $62,50 \%$, ketersediaan alat dan sarana guna menunjang aspek penyimpanan BSE $67,50 \%$, kedisiplinan dalam hal jangka waktu penyimpanan BSE $82,50 \%$, dan keadaan fisik BSE ketika disimpan 35,42\%. Aspek penggunaan BSE termasuk dalam kategori "Sangat Efektif", hal tersebut didukung dengan capaian penyediaan jadwal penggunaan BSE $100 \%$, penggunaan BSE oleh guru $91,67 \%$, penggunaan BSE oleh siswa $100 \%$, keamanan BSE terjamin ketika dipinjam 67,97\%.

Aspek pemeliharaan BSE termasuk dalam kategori "Sangat Efektif", hal tersebut didukung dengan capaian kegiatan prosedur pemeliharaan BSE 90,63\%, rutin dalam pemeliharaan BSE 93,75\%, dan tersedianya biaya pemeliharaan BSE 87,5\%. Aspek penghapusan BSE termasuk dalam kategori "Efektif", hal tersebut didukung dengan capaiaan kegiatan prosedur penghapusan BSE $81,25 \%$ dan waktu penghapusan BSE 75\%.

Tingkat ketercapaiaan tujuan BSE di SMP Negeri Kota Yogyakarta ditinjau dari guru dan siswa. BSE sebagai sumber belajar alternatif bagi siswa, dari sisi guru 68,31\% dengan kriteria "Efektif" dan dari sisi siswa 50,94\% dengan kriteria "Cukup". BSE dapat menstimulus siswa untuk berpikir kreatif dengan bantuan TIK, dari sisi guru 77,56\% dengan kriteria "Efektif" dan 
dari siswa 64,01\% dengan kriteria "Efektif". Mentaati regulasi pemerintah mengenai BSE, dari sisi guru 33,93\% dengan kriteria "Kurang" dan dari sisi siswa 25,16\% dengan kriteria "Kurang".

Saran

Ditinjau dari sisi manajemen BSE pada masing-masing sekolah. Pada aspek perencanaan BSE, akan lebih baik apabila sekolah lebih melibatkan stakeholders dalam menentukan buku yang sesuai dengan siswa. Pada aspek pengadaan BSE, akan lebih baik apabila sekolah juga melakukan pengadaan untuk versi $e$-book. Pada aspek inventarisasi BSE, akan lebih baik lagi apabila sekolah memiliki data mengenai ukuran atau dimensi BSE. Pada aspek penyimpanan BSE, idealnya sekolah harus memiliki media penyimpanan untuk e-book, website sekolah harapanya dapat memuat direct link menuju situs BSE. Pada aspek penggunaan BSE hendaknya antara guru dan siswa tidak dibedakan perlakuannya dalam hal meminjam BSE. Pada aspek pemeliharaan idealnya sekolah menyampul terlebih dahulu BSE yang akan dipinjamkan untuk menjaga usia pakai.

Saran dari segi tujuan program BSE pada aspek menyediakan sumber belajar alternatif, sekolah melalui guru dapat lebih intensif lagi memberikan tugas dengan melibatkan beragam judul BSE selain yang disediakan/dipinjamkan sekolah sebagai buku utama. Versi elektroniknya sekaligus dipergunakan agar fasilitas yang disediakan pemerintah ini dapat benar-benar bermanfaat. Pada aspek menstimulus siswa untuk berpikir kreatif, BSE belum mampu membuat siswa lebih mandiri dalam belajar, sehingga diperlukan sosok guru untuk ikut memberikan dorongan melalui penugasan dan memberikan contoh langsung dalam memanfaatkan BSE melalui TIK. Mematuhi regulasi pemerintah, siswa dan guru diharapkan lebih aktif dalam mencari tambahan referensi dengan mengunduh atau mencetak serta menyebarluaskan BSE.

\section{Daftar Pustaka}

Arikunto, S., \& Jabar, C. S. A. (2014). Evaluasi program pendidikan: Pedoman teoretis praktis bagi praktisi pendidikan. Jakarta: PT Bumi Aksara.

Asiabaka, I. P. (2008). The need for effective facility management in schools in nigeria. New York Science Journal, 10, 10-21.

Burhanudin, Y. (1998). Administrasi pendidikan. Bandung: Pustaka setia.

Certo, S. C., \& Certo, S. T. (2012). Modern management: Concepts and skills. New Jersey: Pearson Education, Inc.

Department of Sport and Recreation Government of Western Australia. (2007). Need assessment sport and recreation facilities. Leederville: Department of Sport and Recreation Government of Western Australia.

Embong, A. M., Noor, A. M., Hasyim, H. M., et al. (2012). E-books as textbooks in the classroom. Kuala Lumpur: Elsevier Ltd. Procedia- Social and Behavioral Sciences 47 (2012) 1802 1809.

Eveline, J. (2011). Pemanfaatan BSE (Buku Sekolah Elektronik) pada guru mata pelajaran produktif di tiga SMK Negeri wilayah Kota Yogyakarta. Tesis magister, tidak diterbitkan. Universitas Negeri Yogyakarta. Diambil pada tanggal 17 Oktober 2015, dari http:/ / eprints.uny.ac.id/5726/1/jo sepha_eveline.pdf.

Fitriyah, A. (2013). Penggunaan BSE (Buku Sekolah Elektronik) sebagai sumber belajar dalam proses pembelajaran ilmu-ilmu sosial di SMA N 1 Tempel. Tesis magister, tidak diterbitkan. Universitas Negeri Yogyakarta. Diambil pada tanggal 18 Juni 2015, dari http:/ / eprints.uny.ac.id.

Frantsi, H., Kolu, K., \& Salminen, S. (2002). A good school library. Espoo: The School Library Association in Fin- 
land The Finnish National Board of Education.

Kementerian Pendidikan Nasional. (2008). Peraturan Menteri Pendidikan Nasional Republik Indonesia Nomor 2 Tahun 2008 tentang Buku.

Nakajima, T., Shinohara, S., \& Tamura, Y. (2013). Typical functions of e-textbook, implementation, and compatibility verification with use of ePub3 materials. Osaka: Elsevier Ltd. Procedia Computer Science 22 (2013) 1344-1353.

Nik-Mat, N. E. M., Kamaruzzaman, S. N., \& Pitt, M. (2011). Assessing the maintenance aspect of facilities management through a performance measurement System: a malaysian case study. The 2nd International Journal Building Control Conference, 20, 329-338.

Prasojo, L. D., \& Wibowo, U. B. (2014). Model pengelolaan pembelajaran berbasis web di sman 1 bambanglipuro kabupaten bantul diy. Jurnal Akuntabilitas Manajemen Pendidikan, 2(1). Retrieved from http://journal.uny.ac.id/index.php /jamp/article/view/2409

Priyono, E. (1 Juli 2012). Salah kaprah tentang buku sekolah elektronik. Kompas, hlm.6.

Salim, D. A. (16 Oktober 2014). Bussines research: Pengguna smartphone menghabiskan waktu 140 menit per hari. SWA, hlm.13.

Siska, S. H., Sundarso, \& Slamet, S. (2014). Evaluasi program BSE kemendikbud di SMA Kota Semarang (studi kasus SMA N 9), Journal of public policy and managemen review, volume 3, no 1. Diambil pada tanggal 19 Oktober 2015, dari http:// ejournals1.undip.ac.id/index.php/jppmr/a rticle/view/4327.

Torlakson, T. (2011). A blueprint for great schools. California: State Superintendent of Public Instruction California Department of Education.

Vincent, J. M. (2012). California's k-12 educational infrastructure investments: Leveraging the state's role for quality school facilities in sustainable communities. Berkeley: Center for Cities \& Schools, University of California.

Zaenal, I., Maya, E. S., Muthia, U. S. (2010). Evaluasi kebijakan BSE di SMA N 8 Kota Yogyakarta. Jurnal AKP. Diakses pada tanggal 18 Oktober 2015, dari journal.uny.ac.id/index.php/pelita /article/download/4298/3723.

Zickuhr, K. (2012). Libraries, patrons, and ebooks. Washington: Pew Research Center's Internet \& American Life Project. 